\title{
THE EFFECT OF FAMILY PROSPERITY BY MATTHEW 18:20 ON THE GROWTH OF THE LOSS OF GKA AGAPE - SURABAYA CONGREGATION
}

\author{
Ani Teguh Purwanto \\ 1) Evangelical Theological Seminary of Indonesia - Surabaya \\ E-mail: aniteguhpurwanto@sttii-surabaya.ac.id
}

\begin{abstract}
This study aims to examine the effect of family altar according to Matthew 18:20 on the spiritual growth of the GKA Agape Surabaya congregation. The reason for this research is due to the low growth of the faith of the congregation due to lack of time to fellowship with God. The sample of this study was 91 people of GKA Agape Surabaya, who were obtained through simple random sampling. The results showed that: 1). there is an influence between the organization of the family altar with the spiritual growth of the church $(r=0.337 ; R$ square $=0.114 ; p=.000)$; 2 ). the contribution independent of the variable implementation of the family altar the dependent variable of the church's spiritual growth was $11.4 \%$. This research implies that when holding a family altar has a positive influence on the growth of the congregation, a congregation that has a good and regular family altar is expected to have good spiritual growth as well.
\end{abstract}

Keywords: family altar, spiritual growth of the congregation.

\section{INTRODUCTION}

Today, only a small amount of time with family often not can be utilized in a quality way. Technology has taken up quality time among families. It is very easy to find a family that is together but immersed in each other's world. Each family member is busy with their affairs, and chooses to communicate with other people from cyberspace, or is busy with games, etc., rather than establishing communication with families who are together. Family togetherness is only physical togetherness, while the hearts and minds of each individual in the family go their separate ways. It shows symptoms that increasingly minimize emotional closeness in human life, especially family.

Within the scope of Christian family life, similar things also occur, so that quality time in Christian family life feels diminishing too. The times of fellowship in the Christian family are also increasingly scarce, which causes spiritual growth in the Christian family to be questioned.

Another thing that is no less important, is that through the development of this increasingly rapid era, has brought humans to lose a lot of valuable time in their lives. The demand to achieve a better quality of life and prosperity has made people race against time.

The survey results of 1,300 teacher respondents, the majority of the opinion that families in the UK spend less time together. Around 56\% think that children spend less time with family than 20 years ago. As many as $94 \%$ of teachers think that the main cause is old age, while $92.5 \%$ of teachers think that the cause is technology. (BBC Electronic Article, 2014)

So the role of parents in a family is only fulfilled in terms of earning a living, thus making quite a lot of valuable time with families lost due to work demands. Thus humans have been trapped to meet their needs and find peace of soul with less priority and rely on God. Julius Ishak Abraham (2010) said that humans are very busy fulfilling the needs of levels one and two, namely the needs of the body and soul, but forgetting the 
important part of spiritual needs that can guarantee the spirit, soul, and body. The mindset of believers, who should have made God their destiny, has undergone a shift, namely to achieve the achievements and welfare of worldly life only. Christ's people have forgotten that without God's help, humans will not be able to achieve any success or peace in their lives. And to get true peace, God's people must again make God their primary focus and purpose in life. Rick Warren (2007) in his book The Power to Change Your Life, states that if humans want peace they must focus on God's presence. Humans must realize that God is always with and humans must learn to feel His presence.

But to be able to focus on God's presence is not possible with human effort and strength. To change the believer's mindset back to the right mindset according to the Christian faith, surely God's help and one's spiritual maturity are needed. The spiritual life of a believer should grow over time. The spiritual growth of believers should always show an increasing graph, although in the increase it is inevitable the dynamics of up and down. Since someone gets his new birth, from then on he must start growing. The spiritual growth of believers is an important and essential thing, even a command that must be carried out by every person who claims to believe in the Lord Jesus Christ. Of the many ways that can be taken to achieve one's spiritual growth, one of them is through the family altar, which is a form of fellowship in the smallest scope. Within this scope or the smallest institution made by God, which is then referred to as a family, God wants to establish fellowship. Pieter Sakul in his book The Marriage Catechesis Guide, explains that from the very beginning God wanted to have fellowship with humans, and not only fellowship personally, but also family for family.

The family altar, also known as the Family Altar, has also been declared an activity recommended for the GKA Agape Surabaya congregation. The program is one of the flagship programs is expected to be one of the solutions to grow the spirituality of the church.

\section{RESEARCH METHODOLOGY}

This study uses quantitative methods that are correlational because this study aims to look at the influence of independent variables (family altar) with dependent variables (spiritual growth of the church). By the objectives of the study, the population in this study was the entire GKA Agape Surabaya congregation aged 17 years and over. Sampling is done by method simple random sampling. It is said to be simple or simple as making members of the sample of the population was randomly without regard to strata that exist in the population. 91 congregations were selected as samples in this study.

Research data collection using a Likert scale and open questionnaire. The scale used to measure the implementation of the family altar and spiritual growth of the jet contains structured questions that give respondents the freedom to choose the answers available. An open questionnaire is used to obtain subject demographic data as well as the data needed to complete the scale.

The instrument regarding the family altar used in this study was a family altar questionnaire consisting of 8 statements. The blueprint questionnaire regarding the family altar is as follows:

\section{Table 1.1 Blueprint of the Family Altar Questionnaire}

\begin{tabular}{|cccc|}
\hline No & Aspect & No Item & Amount \\
\hline $\mathbf{1}$ & God's Word & 1,2 & 2 \\
$\mathbf{2}$ & Prayers & 3,4 & 2 \\
$\mathbf{3}$ & Song & 5,6 & 2 \\
$\mathbf{4}$ & Testimony & 7,8 & 2 \\
Total & & & 8 \\
\hline
\end{tabular}

As for the church's spiritual growth questionnaire, it consists of 25 statements. This instrument uses a Likert scale consisting of four response choices, namely: strongly agree (SS), agree (S), disagree (TS) and strongly disagree (STS). The following is a blueprint for the church's spiritual growth questionnaire:

Table 1.2 Blueprint for Spiritual Growth Questionnaire Church

\begin{tabular}{clcc}
\hline No & \multicolumn{1}{c}{ Aspect } & No Item & Amount \\
\hline 1 & Life literate Word & $\mathbf{9 , 1 0 , 1 1 , 1 2}$ & 4 \\
\hline 2 & Life in prayer & 13,14 & 2 \\
\hline 3 & Life in praise of God & 15,16 & 2 \\
\hline
\end{tabular}




\begin{tabular}{clcc}
\hline 4 & Life that bears witness & $\mathbf{1 7 , 1 8 , 1 9}$ & $\mathbf{3}$ \\
\hline $\mathbf{5}$ & Life that serves & $\mathbf{2 0 , 2 1 , 2 2 , 2 3}$ & $\mathbf{4}$ \\
\hline $\mathbf{6}$ & Living in fellowship & $\mathbf{2 4 , 2 5}$ & $\mathbf{2}$ \\
\hline $\mathbf{7}$ & Life that bears & $\mathbf{2 6 , 2 7 , 2 8}$ & $\mathbf{3}$ \\
\hline $\mathbf{8}$ & $\begin{array}{l}\text { A life that obeys His } \\
\text { commandments }\end{array}$ & $\mathbf{2 9 , 3 0}$ & $\mathbf{2}$ \\
\hline $\mathbf{9}$ & Life of faith & $\mathbf{3 1 , 3 2 , 3 3}$ & $\mathbf{3}$ \\
\hline & Total & & $\mathbf{2 5}$ \\
\hline & This research was & conducted at the
\end{tabular}

This research was conducted at the Abdiel Agape Church in the city of Surabaya. This church is under the auspices of the Abdiel Christian Church Synod which consists of 17 churches spread across many areas on the islands of Java and Bali. This church is in the Pastor Pastor. Pieter Alfons Sakul has pastored this church since its inception, namely in 2001.

While the time of this research was conducted in June and July 2015 to coincide with the family month that is held every year in this church. Besides, determining the time that coincides with this family month will be easier to remind the congregation of the family altar program that was two years ago that was once socialized to the congregation, which was also at the same moment, the family month.

The analysis technique used in testing this hypothesis is to use the Pearson Product Moment Correlation to see the effect between the family altar and the spiritual growth of the congregation. Before testing the hypothesis, the assumption test first includes the normality test and the linearity test. Data distribution requirements are said to be normally distributed if $p>0.01$, while the terms of the relationship between variables are linear functions if $\mathrm{p}<0.01$.

\section{RESULTS AND DISCUSSION}

\section{Table 1.3 Identity of Subjects by Gender}

\begin{tabular}{ccc}
\hline Gender & Frequency & Percentage \\
\hline Men & 45 & 49 \\
\hline Women & 46 & 51 \\
\hline Total & 91 & 100 \\
\hline
\end{tabular}

From table 1.3 it is known that $51 \%$ of subjects are female and $49 \%$ of subjects are male.

Table 1.4 Subjects Identity based on Age

\begin{tabular}{ccc}
\hline Age Respondents & Frequency & Percentage \\
\hline $\mathbf{2 0 - 3 0}$ th & 22 & $24 \%$ \\
\hline $\mathbf{3 1 - 4 0}$ th & 18 & $20 \%$ \\
\hline $\mathbf{4 1 - 5 0}$ th & 35 & $38 \%$ \\
\hline $\mathbf{5 1 - 6 0}$ th & 10 & $11 \%$ \\
\hline$>\mathbf{6 0}$ th & 6 & $7 \%$ \\
\hline Total & 91 & 100 \\
\hline
\end{tabular}

From the table 1.4 known that $24 \%$ of subjects aged $20-30$ years, and $38 \%$ of subjects aged 41-50 years.

\section{Table 1.5 Subject Identity based on Education Level}

\begin{tabular}{lcc}
\hline \multicolumn{1}{c}{ Education } & Frequency & Percentage \\
\hline Doctoral Degree & 1 & 1 \\
\hline Magister & 8 & 9 \\
\hline Bachelor & 53 & 58 \\
\hline Diploma & 2 & 2 \\
\hline Senior High School & 23 & 25 \\
\hline Junior High School & 4 & 4 \\
\hline Elementary school & 0 & 0 \\
\hline Total & 91 & 100 \\
\hline
\end{tabular}

From table 1.5 it appears that no respondent only enjoyed education level up to elementary school, or $0 \%$. Respondents who completed education up to junior high school were 4 people or $4 \%$, and consecutive high schools were 23 people or $25 \%$, D3 was only 2 people or $2 \%, 53$ people were $\mathrm{S} 1$ or $58 \%, 8$ people were $\mathrm{S} 2$ or $9 \%$ and the last is S3 for 1 person or $1 \%$. Therefore it can be concluded that the majority of GKA Agape congregations have a fairly high level of education.

\section{DESCRIPTIVE STATISTICS ON PRACTICES OF FAMILY ALTAR ELEMENTS}

Table 1.6 Aspects of God's Word-1

\begin{tabular}{lcc}
\hline \multicolumn{1}{c}{$\begin{array}{c}\text { Contemplating FT } \\
\text { regularly }\end{array}$} & Frequency & Percentage \\
\hline Never & 9 & 9,9 \\
\hline Every few months & 15 & 16,5 \\
\hline times a month & 48 & 52,7 \\
\hline More than once a week & 19 & 20,9 \\
\hline Total & 91 & 100 \\
\hline
\end{tabular}

From table 1.6 it can be seen that the subject's answers to the questionnaire question: "I regularly meditate on the truth of God's Word with my family", apparently 9 people $(9.9 \%)$ had never done it, 15 people $(16.5 \%)$ every few months, 48 people $(52.7 \%)$ do it 1-4 times a month, and 19 people $(20.9 \%)$ do it fairly routinely, that is, more than once a week. 
Table 1.7 Aspects of God's Word-2

\begin{tabular}{lcc}
\hline Discuss FT with family & Frequency & Percentage \\
\hline Never & 6 & 6,6 \\
\hline Once a few months & 17 & 18,7 \\
\hline Times A Month & 61 & 67,0 \\
\hline More than once a week & 7 & 7,7 \\
\hline Total & 91 & 100 \\
\hline
\end{tabular}

From table 1.7 it appears that the subject's answers to the questionnaire question: "I often discuss the truth of God's Word with family", and it turns out as many as 6 people (6.6\%) who have never done it, 17 people (18.7\%) every few months do it, 61 people (67\%) do it 1-4 times a month, and only 7 people $(7.7 \%)$ do it quite regularly, ie more than once a week.

\section{Table 1.8 Aspects of Prayer - 1}

\begin{tabular}{lcc}
\hline Pray regularly with family & Frequency & Percentage \\
\hline Never & 4 & 4,4 \\
\hline Several months & 17 & 18,7 \\
\hline times a month & 42 & 46,2 \\
\hline More than once a week & 28 & 30,8 \\
\hline Total & 91 & 100
\end{tabular}

From table 1.8 seen that the answer to the subject regarding the questionnaire question: "I regularly pray to God with my family", and it turns out as many as 4 people $(4.4 \%)$ who have never done it, 17 people (18.7\%) every few months do it, 42 people (46.2\%) do it 1-4 times a month, and 28 people $(30.8 \%)$ do it fairly routinely, that is, more than once a week

\section{Table 1.9 Prayer Aspects - 2}

\begin{tabular}{lcc}
\hline Taking time to grateful & Frequency & Percentage \\
\hline Never & 7 & 7,7 \\
\hline A few months & 14 & 15,4 \\
\hline times a month & 36 & 39,6 \\
\hline More than once a week & 34 & 37,4 \\
\hline Total & 91 & 100 \\
\hline
\end{tabular}

From table 1.9 you can see that the subject's answers regarding the questionnaire question: "I am with families routinely make time to give thanks to God in prayer ", and it turns out as many as 7 people $(7.7 \%)$ who have never done it, 14 people $(15.4 \%)$ every few months do it, 36 people (39.6\%) who do it as much as 1 - 4 times a month, and as many as 34 people $(37.4 \%)$ do it fairly routinely, ie more than once a week
Table 1.10 Aspects of Hymns - 1

\begin{tabular}{lcc}
\hline \multicolumn{1}{c}{$\begin{array}{c}\text { Raise gratitude through } \\
\text { praise }\end{array}$} & frequency & Frequency \\
\hline Never & 11 & 12,1 \\
\hline Once a few months & 26 & 28,6 \\
\hline Times a month & 34 & 37,4 \\
\hline More than once a week & 20 & 22,0 \\
\hline Total & 91 & 100 \\
\hline
\end{tabular}

From table 1.10 it appears that the subject's answers to the questionnaire questions: "I raise gratitude to God through praise with family ", and it turns out 11 people $(12.1 \%)$ have never done it, 26 people (28.6\%) do it every few months, 34 people (37.4\%) do it 1-4 times a month, and as many as 20 people $(22 \%)$ do it fairly regularly, which is more than once a week.

Table 1.11 Aspects of Hymns - 2

\begin{tabular}{lcc}
\hline \multicolumn{1}{c}{ Praising God with family } & frequency & Frequency \\
\hline Never & 12 & 13,2 \\
\hline Once a few months & 28 & 30,8 \\
\hline Times a month & 40 & 44,0 \\
\hline More than once a week & 11 & 12,1 \\
\hline Total & 91 & 100 \\
\hline
\end{tabular}

From table 1.11 seen that the answer to the subject regarding the question questionnaire: "I and my family often take the time to sing together to praise God", and it turns out as many as 12 people $(13.2 \%)$ who have never done it, 28 people $(30.8 \%)$ every few months do it, 40 people $(44 \%)$ do it $1-4$ times a month, and only 11 people $(12.1 \%)$ do it quite regularly, which is more than once a week.

\section{Table 1.12 Witness Aspects - 1}

\section{Witness among family frequency Frequency members}

\begin{tabular}{lcc}
\hline Never & 5 & 5,5 \\
\hline Once a few months & 27 & 29,7 \\
\hline Times a month & 52 & 57,1 \\
\hline More than once a week & 7 & 7,7 \\
\hline Total & 91 & 100 \\
\hline
\end{tabular}

From table 1.12 seen that the answer to the subject regarding the questionnaire question: "I often exchange testimonies about living with God with my family", and it turns out as many as 5 people $(5.5 \%)$ who have never done it, 27 people $(29.7 \%)$ every few months do it, 52 people $(57.1 \%)$ do it $1-4$ 
times a month, and only 7 (7.7\%) do it fairly routinely, more than once a week.

\section{Table 1.13 Witness Aspects - 2}

\begin{tabular}{lcc}
\hline $\begin{array}{c}\text { Sharing testimonies of life } \\
\text { with God }\end{array}$ & frequency Frequency \\
\hline Never & 7 & 7,7 \\
\hline Once a few months & 30 & 33,0 \\
\hline Times a month & 48 & 52,7 \\
\hline More than once a week & 6 & 6,6 \\
\hline Total & 91 & 100 \\
\hline
\end{tabular}

From table 1.13 seen that the answer to the subject regarding the questionnaire question: "I and my family always share testimonies of life with God", and it turns out as many as 7 people $(7.7 \%)$ who have never done it, 30 people $(33 \%)$ every few months do it, 48 people $(52,7 \%)$ do it $1-4$ times a month, and only $6(6.6 \%)$ do it fairly routinely, that is, more than once a week.

From the eight statements in the questionnaire that discuss the frequency of implementation of the family altar, it can be concluded that the majority of congregations do these elements only as much as one to four times a month. This shows that the frequency of the implementation of the family altar is not done often enough in the daily congregation.

\section{The influence of the family altar on the spiritual growth of the congregation}

The normality assumption test is done first before testing the hypothesis. The results of the church's spiritual growth test data have a normal distribution because of the Kolmogorov-Smirnov p-value 0.869> 0.05. The data distribution is normally distributed so that the hypothesis test can be done with the parametric test for the $\mathrm{Y}$ variable.

The influence of the family altar on the spiritual growth of the congregation is tested using linear regression. The results of testing the influence of the family altar on the spiritual growth of the congregation are in Table 1.14.

\begin{tabular}{cccccc}
\hline $\begin{array}{c}\text { Effect of Variable } \\
\text { R }\end{array}$ & $\mathbf{R}^{2}$ & $\mathbf{P}$ & Description \\
\hline $\begin{array}{c}\text { Altar of the family } \\
\text { against spiritual } \\
\text { growth of the } \\
\text { church }\end{array}$ & 0.337 & 0.114 & 0.000 & $\begin{array}{c}\text { There is an } \\
\text { effect }\end{array}$ \\
& & & & \\
\hline
\end{tabular}

Hypothesis test results using linear regression obtained the value of $\mathrm{R}=0337, \mathrm{R} 2$ $=0.114$ and $p=0.000(<0.05)$, so Ho rejected. Thus there is the influence of the family altar on the spiritual growth of the church.

\section{Discussion}

Family altar means family members who offer time to worship God together at home. Building a family altar is an important work in a Christian's home because it confirms that God is the center of the household. Humans need His guidance just as Abram did. The family altar also gives family members a private place to worship God, discuss spiritual matters and pray as a family. Building a family altar aims as the key to building a strong family in God.

The purposes of the family altar include worshiping God as a family, making the family rooted in faith and God's Word, bridging the gap in the family and offering prayers in the family altar. A family altar can be more formal than church services but must be solemn. No need to be too rigid but can be flexible. The service must be more interactive and more vibrant than one-way preaching. Although it is less formal, the family altar should not lose its purpose or direction.

The family altar influences the spiritual growth of the church. For this reason, the family altar must first take root in the hearts of parents. A father, as head of the family, must take the initiative to plan and conduct family services.

God has handed over responsibilities to parents, especially fathers, to supervise the faith of children. If as a parent, a father manages to build a family altar, then children will have deep roots in respect, trust and love for God. Therefore, every family must teach children to fulfill their duties to God and obey His voice and commands (Deut 30: 2). Parents must set an example so that children can imitate in faith, love, and moral integrity.

Parents can ask for the child's involvement in leading part or all of this family service, but it is the father who remains always the spiritual overseer. Providing opportunities for children to lead at home will practice leadership skills and confidence, which in turn will prepare children to serve as leaders in the church later. All family members must be allowed to contribute to family services because everyone must be valued for their service and service to God.

The family altar is not a strange thing in the life of God's people. Evidenced by the 
verse used by the author to base the family altar, namely from Matthew 18:20. Although this verse is part of the context of advising your fellow brothers, however, as explained in chapter II, it turns out that this verse is not only bound to the context, but rather underlines the context of the passage, because the fellowship between 2 or more people in His name has been becoming a common practice carried out by the Israelites, and this concept was used to reinforce the passage. Therefore, although the concept of the family altar is not written in the Bible, except through Matthew 18:20 which is often misinterpreted only related to pericope context, but this is very relevant to the family altar and even very important to be carried out in all ages because it has been proven from time to time since the beginning of human life, this family altar is desired and acceptable by God.

Knowing that the family altar is actually also a command of God, and not just an additional activity in the life and daily life of God's people which adds inconvenience, then the family altar will have the right portion and attention from God's people, and carried out in daily life, so that through this family altar of God's people can increasingly exalted and glorify God, so that through it the people of God will get spiritual blessings and always grow in him.

\section{Conclusions and Suggestions}

\section{Conclusions}

Based on the problems and discussion about the influence of the family altar on the spiritual growth of the church, it can be concluded as follows:

1. Acceptance of the hypothesis that there is the influence of the family altar on the spiritual growth of the church with a value of $r$ $=0.337$ and $p=0.000$. The higher the family altar the higher the spiritual growth of the church.

2. The effective contribution of the family altar to the spiritual growth of the church is $11.4 \%$.

\section{Suggestion}

Based on the conclusion that there is an influence of the family altar on the spiritual growth of the congregation, then every Christian family is expected to be able to offer time to worship God together at home, because if each family can build a strong family altar - an altar that is acceptable and blessed by God in real.

For the Pastor, the Servant of the Lord and the Church Assembly as the ones in charge of bringing the church in the right direction according to God's will, it is hoped that the church's authority will be in charge of designing practical programs to be carried out on the church agenda. A few years later, this authority designed the socialization of the family altar as one of the church programs in GKA Agape.

[1]. Abraham, Julius Ishak. Memulihkan Taman Eden Dalam Keluarga. Yogyakarta: ANDI, 2010.

[2]. Alkitab Edisi Studi - The Learning Bible Contemporary. Jakarta: Lembaga Alkitab Indonesia, 2011.

[3]. Sakul, Pieter. Buku Pedoman Katekesasi Pernikahan. Surabaya: Sinode Gereja Kristen Abdiel, 2005.

[4]. Warren, Rick. God's Power To Change Your Life. Diterjemahkan oleh Nuel Hermanto M. Disunting oleh Ingouf Setiawan, Kusnadi Kunawi. Jakarta: Metanoia Publishing, 2007.

[5]. E-Artikel BBC Indonesia. Waktu Bersama Keluarga Makin Sedikit. April 2014. http://www.bbc.com/indonesia/majalah/2014/ 04/140415_pendidikan_keluarga 